THE BIOPOLITICS OF STALINISM 



\section{THE BIOPOLITICS OF STALINISM}

Ideology and Life in Soviet Socialism

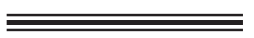

Sergei Prozorov 


\section{To Marina and Pauliina, in captivation}

Edinburgh University Press is one of the leading university presses in the UK. We publish academic books and journals in our selected subject areas across the humanities and social sciences, combining cutting-edge scholarship with high editorial and production values to produce academic works of lasting importance. For more information visit our website: www.edinburghuniversitypress.com

CC Sergei Prozorov, 2016

Edinburgh University Press Ltd

The Tun - Holyrood Road

12 (2f) Jackson's Entry

Edinburgh EH8 8PJ

Typeset in I I/I 3 Adobe Sabon by IDSUK (DataConnection) Ltd, and printed and bound in Great Britain by CPI Group (UK) Ltd, Croydon CRo 4 YY

A CIP record for this book is available from the British Library

ISBN 9781474410526 (hardback)

ISBN 9781474410533 (paperback)

ISBN 9781474410540 (webready PDF)

ISBN 9781474410557 (epub)

The right of Sergei Prozorov to be identified as author of this work has been asserted in accordance with the Copyright, Designs and Patents Act 1988 and the Copyright and Related Rights Regulations 2003 (SI No. 2498). 